\title{
Quantitative structure-activity relationships for the mutagenicity of propylene oxides with Salmonella
}

\author{
B.H. Hooberman, P.K. Chakraborty and J.E. Sinsheimer \\ College of Pharmacy, University of Michigan, Ann Arbor, MI 48109-1065, USA \\ (Received 29 June 1992) \\ (Revision received 27 October 1992) \\ (Accepted 30 October 1992)
}

Keywords: Propylene oxides; Aliphatic epoxides; Salmonella mutagenicity; Structure-activity relationships

\section{Summary}

A quantitative structure-activity relationship approach was used to investigate the mutagenicity of a series of seventeen-monosubstituted propylene oxides in Salmonella typhimurium strains TA100 and TA1535. Mutagenicity in strain TA100, using a liquid suspension assay, was found to correlate with chemical reactivity, as measured by the rates of reaction with two model bionucleophiles, nicotinamide and 4-(4-nitrobenzyl)pyridine. However, since the reactivity of three of the epoxides did not correlate to their Taft $\sigma^{*}$ values, as a measure of the electronic effects of substituent groups, neither was their mutagenicity predicted by this substituent constant. The relative mutagenicity for the propylene oxides was different in the liquid suspension assay than that determined by the standard plate incorporation assay and also differed between the two bacterial strains. The assay differences were attributed to epoxide stability. The differences between strains was observed to be due to the response of the error-prone repair system, found only in TA100, to the stronger alkylating agents.

Aliphatic epoxides have found widespread use as valuable industrial and laboratory alkylating agents, which has led to much interest in their potential genotoxicity (Manson, 1980; Ehrenberg and Hussain, 1981). In surveys of commercially available aliphatic epoxides using Salmonella ty-

Correspondence: Dr. J.E. Sinsheimer, College of Pharmacy, University of Michigan, Ann Arbor, MI 48109-1065 (USA). phimurium in the Ames assay, Wade et al. (1978) and Canter et al. (1986) found that mutagenic activity varies widely with the chemical structure of the epoxide. Both studies reported that these epoxides were direct-acting mutagens and that the presence of electron-withdrawing substituent groups on the epoxide ring increased mutagenicity. Studies using Neurospora crassa (Kolmark and Giles, 1955), Escherichia coli WP2 uvrA (Hemminki and Falck, 1979) and Klebsiella pneumoniae (Voogd et al., 1981) also found that the presence of electron-withdrawing groups led to 
increased mutagenic activity. In an in vitro mammalian cell assay, analysis of sister-chromatid exchange frequencies in Chinese hamster V79 cells gave results in general agreement with those of Wade et al. (1978) with respect to the effect of electron-withdrawing groups (von der Hude et al., 1991).

Work in our laboratory has centered on establishing quantitative structure-activity relationships (QSAR) for series of closely related aliphatic epoxides in the Ames test. The mutagenicity of glycidyl phenyl ether and six para-substituted derivatives was found to correlate with the Hammett substituent constant as a measure of the electronic effects of aromatic substituent groups (Neau et al., 1982). A multiple regression analysis model was developed to describe the mutagenicity of a series of five para-substituted $\alpha$-methylstyrene oxides (Rosman et al., 1986). While van der Waals volume was the most important variable in the model, Hammett values played a lesser but significant role. Several aryl propylene and aryl butylene oxides were tested for mutagenicity, but these epoxides only showed weak correlations to physicochemical parameters (Rosman et al., 1987). No correlations could be established for the mutagenicity of a series of aromatic glycidyl ethers, although it was noted that increased conjugated aromatic substitution led to increased mutagenicity (Rosman et al., 1988).

We have previously reported, for a series of propylene oxides (Nelis et al., 1982), on the correlation between alkylating ability and Taft $\sigma^{*}$ values, which measure the electron-withdrawing strength of substituent groups in aliphatic systems. Subsequent studies on propylene oxide and three derivatives demonstrated a correlation between Taft $\sigma^{*}$ values and reactivity to the deoxynucleosides in DNA (Djuric et al., 1986). The same study also noted a relationship between deoxynucleoside reactivity and mutagenicity in Salmonella. Hemminki and Falck (1979) reported a correlation between 4-(4-nitrobenzyl)pyridine (NBP) alkylation and mutagenicity in Salmonella and $E$. coli for the same four epoxides.

In the present investigation, a series of propylene oxides has been extended to include seventeen members in a quantitative structure-mutagenicity study. Mutagenicity to Salmonella is re- lated to alkylating strength, Taft $\sigma^{*}$ values and other physicochemical parameters of substituent groups that may affect mutagenic activity. It was also of interest to examine further the finding reported in Djuric et al. (1986) that the method used to establish mutagenicity influences the relative order of mutagenic potency. The two procedures, a liquid suspension assay and the standard plate incorporation test, were compared and the results used in a regression model to determine methodological factors that influence the measurement of relative mutagenic potency.

\section{Materials and methods}

\section{Epoxides}

1,2-Epoxypropane (propylene oxide), 1,2-epoxy-3-chloropropane (epichlorohydrin), 1,2-epoxy3-bromopropane (epibromohydrin), 1,2-epoxy-3fluoropropane (epifluorohydrin), 1,2-epoxybutane (butylene oxide), 1,2-epoxy-3,3,3-trichloropropane (trichloropropylene oxide), 1,2-epoxy-3-methoxypropane (glycidyl methyl ether) and glycidol were obtained from Aldrich Chemical Company, Inc. (Milwaukee, WI). Additional supplies of 1,2epoxy-3,3,3-trichloropropane and 1,2-epoxy-3methoxypropane were purchased from Pfaltz and Bauer, Inc. (Stamford, CN). 2,3-Epoxypropyltrimethylammonium chloride (glycidyl trimethylammonium chloride) was obtained from Fluka Chemical Corp. (Ronkonkoma, NY). These epoxides, except for propylene oxide, epifluorohydrin, and glycidyl trimethylammonium chloride, were purified by redistillation under reduced pressure $(<5 \mathrm{~mm})$.

1,2-Epoxy-3-cyanopropane (epicyanohydrin) was synthesized from its allylic precursor, allyl cyanide (Aldrich) by the procedure of Van Duuren et al. (1971). 1,2-Epoxy-3-butanone and glycidic acid methyl ester, were prepared by the method of Wellman et al. (1976). 1,2-Epoxy-3iodopropane (epiiodohydrin) was prepared from epibromohydrin and potassium iodide by the procedure of Nef (1904).

1,2-Epoxy-3,3-dichloropropane (dichloropropylene oxide) was synthesized by the reaction of diazomethane and dichloroacetaldehyde with purification by chromatography over silica gel as described in Sinsheimer et al. (1987). 1,2-Epoxy- 
3,3-dibromopropane (dibromopropylene oxide) and 1,2-epoxy-3,3,3-tribromopropane (tribromopropylene oxide) were prepared by similar reactions of diazomethane and their corresponding aldehydes. While tribromoacetaldehyde was commercially available (Aldrich), the dibromoacetaldehyde was prepared by bromination of acetaldehyde (Karabatsos et al., 1969). Tribromopropylene oxide was a liquid with boiling point 95-96 ${ }^{\circ} \mathrm{C} / 10 \mathrm{~mm} .{ }^{1} \mathrm{H}-\mathrm{NMR}:\left(\mathrm{CDCl}_{3}, 270 \mathrm{MHz}\right)$ $\delta, 3.75(\mathrm{~d}, 1 \mathrm{H}, \mathrm{CH}), 3.23\left(\mathrm{~m}, 1 \mathrm{H}, \mathrm{CH}_{2}\right), 3.07(\mathrm{~m}$, $1 \mathrm{H}, \mathrm{CH}_{2}$ ). Dibromopropylene oxide solidified upon refrigeration with melting point $34-36^{\circ} \mathrm{C}$. ${ }^{1} \mathrm{H}-\mathrm{NMR}:\left(\mathrm{CDCl}_{3}, 270 \mathrm{MHz}\right) \delta, 5.24(\mathrm{~d}, 1 \mathrm{H}$, $\left.\mathrm{CHBr}_{2}\right), 3.58(\mathrm{~m}, 1 \mathrm{H}, \mathrm{CH}), 3.10\left(\mathrm{dd}, 1 \mathrm{H}, \mathrm{CH}_{2}\right.$ ), $2.86\left(\mathrm{~m}, 1 \mathrm{H}, \mathrm{CH}_{2}\right)$.

The purity of all epoxides was examined by thin layer chromatography (TLC) using $1 \mu \mathrm{l}$ of epoxide neat, on Silica-GF Uniplates $(2 \mathrm{~cm} \times 10$ $\mathrm{cm}, 250 \mu$; Analtech, Newark, DE) using two solvent systems, dichloromethane and ethyl acetate. The compound was established to be suitable for testing when a single homogeneous spot was visualized under short-wavelength UV light and by spraying with NBP (Aldrich), a test to detect alkylating agents (Hammock et al., 1974).

\section{Rates of alkylation and hydrolysis}

The rates of alkylation were compared by reaction of the epoxides at equimolar concentrations at $37^{\circ} \mathrm{C}$ for $20 \mathrm{~min}$ as previously described with NBP (Nelis et al., 1982) and with nicotinamide (Calbiochem, Los Angeles, CA) by the procedure of Nelis et al. (1981).

The rates of hydrolysis were determined as in Giri et al. (1990), with the exception that the reaction mixture contained $23.75 \mathrm{ml}$ phosphate buffer and $1.25 \mathrm{ml}$ of a $40 \mathrm{mM}$ solution of epoxide in dimethylsulfoxide. Due to their low alkylation rates, six epoxides required a $30 \mathrm{~min}$ NBP incubation time. These compounds were propylene oxide, butylene oxide, methyl glycidyl ether, 1,2-epoxy-3-butanone, glycidic acid methyl ester and glycidyl trimethylammonium chloride. The resulting plots of absorbance versus time for all epoxides gave curves that were best described by first order rate kinetics, according to the following equation: $Y=a\left(\mathrm{e}^{-b X}\right)$, where $b$ is the decay rate parameter used in the QSAR analysis.

\section{Partition coefficients}

Reverse-phase high-performance liquid chromatography (HPLC) was used to determine relative partition coefficients for the propylene oxide series of compounds (Carlson et al., 1975). The mobile phase was $10 \%(\mathrm{v} / \mathrm{v})$ methanol in water at a flow rate of $1.0 \mathrm{ml} / \mathrm{min}$. The retention times were used to calculate the capacity factor $k^{\prime}$ according to the following formula: $k^{\prime}=\left(t_{R}-\right.$ $\left.t_{O}\right) / t_{O}$, where $t_{R}$ was the compound retention time and $t_{O}$ was the solvent front void time. The partition coefficients, $P$, relative to propylene oxide, were calculated according to the equation: $P=\log \left(k_{\text {compound }}^{\prime}-k_{\text {propylene oxide }}^{\prime}\right)$.

\section{Mutagenicity assays}

Salmonella typhimurium strains TA100 and TA1535 were kindly provided by Dr. Bruce Ames (University of California, Berkeley, CA). The strains were maintained and routinely screened for their proper genetic characteristics as described by Maron and Ames (1983). Cultures were grown by inoculating nutrient broth with the test strain the night before the test and then placed in a $37^{\circ} \mathrm{C}$ incubator overnight. Cultures were removed to a water bath and shaken at $37^{\circ} \mathrm{C}$ until they reached an absorbance of 0.78 to 0.85 at $560 \mathrm{~nm}$.

The plate incorporation assay (PIA) was performed as described by Maron and Ames (1983). The procedures for the liquid suspension assay (LSA) were as defined in Djuric et al. (1986). For all mutagenicity testing, dose-response determinations were performed in triplicate and repeated on at least a second day. Colony counting was performed manually, and for those plates where counts exceeded 2000, the plates were subdivided into equal sections and the number of counts in several representative sections were determined and multiplied by the appropriate factor.

\section{Statistics}

The slope of the linear range of the dose-response curve for each epoxide was determined using the statistical procedures described by Bernstein et al. (1982). The calculations were performed using the SYSTAT (SYSTAT, Inc., 
Evanston, IL) statistical program for personal computers.

\section{Results and discussion}

The physicochemical properties of the propylene oxides are listed in Table 1. Electronic effects of substituent groups in aliphatic compounds are represented by Taft $\sigma^{*}$ values. The Taft $E_{\mathrm{s}}$ constants, molar refractivity $(M R)$ and the STERIMOL parameters $\left(L, B_{1}, B_{2}, B_{3}\right.$ and $B_{4}$ ) measure steric effects. Molecular volumes $(v W)$ were calculated according to Moriguchi et al. (1976). Partition coefficients, rates of decay (or hydrolysis), and chemical reactivity, as measured by the alkylation of two model nucleophiles, NBP and nicotinamide, were determined experimentally and are given in Table 2 . The results from the two alkylation assays were highly correlated $(r=0.99)$, indicating little difference in the rela- tive rates of reaction of the epoxides toward either model bionucleophile.

Mutagenicity was determined by two methods, PIA and LSA, and in two strains, TA100 and TA1535. The mutagenic potencies of the propylene oxides, as measured by the slope of the linear range of the dose-response curve for each compound, are given in Table 3 for both assays and both bacterial strains. The LSA, where exposure occurs in a stoppered tube, was originally employed to address the problem of compound volatility, particularly for propylene oxide. The results do show greater mutagenicity for propylene oxide in the LSA than in the PIA, but there were disproportionate increases in mutagenicity for other epoxides in the series, especially for glycidol, the dichloro and the trichloro compounds. These differences were evident when the correlation between mutagenicity and alkylating strength was examined. A strong correlation was found between mutagenicity in TA100 as determined using the LSA and alkylation to nicotin-

TABLE 1

PROPYLENE OXIDE SUBSTITUENT PARAMETERS ${ }^{\text {a }}$

\begin{tabular}{|c|c|c|c|c|c|c|c|c|c|}
\hline Substituent & $\sigma^{*}$ & $E_{s}$ & $\mathrm{~L}$ & $\mathrm{~B}_{1}$ & $\mathrm{~B}_{2}$ & $\mathrm{~B}_{3}$ & $\mathbf{B}_{4}$ & MR & $\mathrm{vW}$ \\
\hline $\mathrm{CH}_{3}$ & 0.00 & -1.24 & 3.00 & 1.52 & 1.90 & 1.90 & 2.04 & 5.65 & 0.245 \\
\hline $\mathrm{CH}_{2} \mathrm{CH}_{3}$ & -0.10 & -1.31 & 4.11 & 1.52 & 1.90 & 1.90 & 2.97 & 10.30 & 0.399 \\
\hline $\mathrm{CH}_{2} \mathrm{OH}$ & 0.56 & -1.21 & 3.97 & 1.52 & 1.90 & 1.90 & 2.70 & 7.19 & 0.313 \\
\hline $\mathrm{CH}_{2} \mathrm{OCH}_{3}$ & 0.52 & -1.43 & 4.91 & 1.52 & 1.90 & 1.90 & 2.88 & 12.06 & 0.480 \\
\hline $\mathrm{CH}_{2} \mathrm{OC}_{6} \mathrm{H}_{5}$ & 0.85 & -1.57 & 8.19 & 1.52 & 3.09 & 3.11 & 3.11 & 31.74 & 1.020 \\
\hline $\mathrm{CH}_{2} \mathrm{~F}$ & 1.10 & -1.48 & 3.30 & 1.52 & 1.90 & 1.90 & 2.61 & 5.43 & 0.291 \\
\hline $\mathrm{CH}_{2} \mathrm{Cl}$ & 1.05 & -1.48 & 3.89 & 1.52 & 1.90 & 1.90 & 3.46 & 10.49 & 0.380 \\
\hline $\mathrm{CHCl}_{2}$ & 1.94 & -2.78 & 3.89 & 2.04 & 2.63 & 3.24 & 3.24 & 15.30 & 0.515 \\
\hline $\mathrm{CCl}_{3}$ & 2.65 & -3.30 & 3.89 & 2.63 & 3.24 & 3.24 & 3.46 & 20.12 & 0.650 \\
\hline $\mathrm{CH}_{2} \mathrm{Br}$ & 1.00 & -1.51 & 4.09 & 1.52 & 1.95 & 1.95 & 3.75 & 13.39 & 0.416 \\
\hline $\mathrm{CHBr}_{2}$ & $1.85^{b}$ & -3.10 & 4.09 & 2.04 & 2.85 & 3.50 & 3.50 & 16.75 & 0.587 \\
\hline $\mathrm{CBr}_{3}$ & 2.50 & -3.67 & 4.09 & 2.86 & 3.50 & 3.50 & 3.75 & 28.81 & 0.758 \\
\hline $\mathrm{CH}_{2} \mathrm{I}$ & 0.85 & -1.61 & 4.36 & 1.52 & 2.15 & 2.15 & 4.15 & 18.60 & 0.504 \\
\hline $\mathrm{CH}_{2} \mathrm{CN}$ & 1.30 & -2.38 & 3.99 & 1.52 & 1.90 & 1.90 & 4.12 & 10.11 & 0.422 \\
\hline $\mathrm{COCH}_{3}$ & 1.65 & & 4.06 & 1.90 & 1.90 & 2.36 & 2.93 & 11.18 & 0.420 \\
\hline $\mathrm{CO}_{2} \mathrm{CH}_{3}$ & 2.00 & & 4.85 & 1.90 & 1.90 & 2.36 & 3.36 & 12.87 & 0.501 \\
\hline $\mathrm{CH}_{2} \mathrm{~N}^{+}\left(\mathrm{CH}_{3}\right)_{3}$ & 1.90 & -4.13 & 4.96 & 1.52 & 2.80 & 2.80 & 3.94 & & 0.848 \\
\hline
\end{tabular}

a The substituent parameters $\sigma^{*}$, Taft electronic; $\mathrm{E}_{\mathrm{s}}$, Taft steric; $\mathrm{L}, \mathrm{B}_{1}, \mathrm{~B}_{2}, \mathrm{~B}_{3}, \mathrm{~B}_{4}$, Verloop steric; and MR, Molar refractivity, were obtained from the compilation of Hansch and Leo (1979). vW, van der Waals volume, calculated according to Moriguchi et al. (1976).

b Value estimated from available values for mono-, di- and tri-fluoro, -chloro and -bromo substituent groups. 
amide $(r=0.96)$, whereas the correlation diminished for the mutagenicity as determined in the PIA $(r=0.64)$.

The mutagenicity of the propylene oxides, in the TA100 ${ }_{\text {LSA }}$, was best described by the electronic effects of the substituent groups. Fig. 1 shows the relationship between mutagenicity, expressed as a $\log$ function, and Taft $\sigma^{*}$ values. When the regression line in the graph was calculated from the data excluding three compounds, the $\mathrm{COCH}_{3}, \mathrm{COOCH}_{3}$ and $\mathrm{CH}_{2} \mathrm{~N}^{+}\left(\mathrm{CH}_{3}\right)_{3}$ derivatives, whose $\sigma^{*}$ values were not predictive of their alkylating ability, the correlation coefficient is 0.95 but is significantly lower with all compounds included $(r=0.61)$. That is, the mutagenicity of these three structurally distinct compounds is substantially lower than that predicted by their $\sigma^{*}$ values.

In addressing the lack of correlation between the LSA and PIA procedures, it was noted that glycidol, which had greater activity in the PIA, is one of the most water-soluble members of the series and the di- and tri-chloro compounds, which showed greater activity in the LSA, are among the least soluble propylene oxides. Therefore, the differences between the methods might be explained by partition effects. To test if partition effects could account for method differences, a multiple regression model for the propylene oxides was developed where the mutagenicity in TA100 ${ }_{\text {LSA }}$ was defined as a function of the mutagenicity in TA100 ${ }_{\mathrm{PIA}}$ and an additional parameter. If no additional parameter was included, the correlation coefficient was 0.79 . Inclusion of the partition coefficient parameter did not yield a higher correlation. None of the parameters in Table 1 measuring hydrophobic or steric effects improved the correlation.

A second possible explanation of the differences between the results of the two assays relates to the exposure time of the epoxide to the bacteria. Norppa et al. (1981) reported the effects

TABLE 2

PARTITION, DECAY AND ALKYLATION SUBSTITUENT PARAMETERS FOR, THE PROPYLENE OXIDES

\begin{tabular}{|c|c|c|c|c|}
\hline \multirow[t]{2}{*}{ Substituent } & \multirow{2}{*}{$\frac{\text { NBP }^{a}}{\text { Ave. } \pm \text { S.E. }}$} & \multirow{2}{*}{$\frac{\text { Nicotinamide }^{a}}{\text { Ave. } \pm \text { S.E. }}$} & \multirow[t]{2}{*}{ Partition $^{b}$} & \multirow[t]{2}{*}{ Decay $^{c}$} \\
\hline & & & & \\
\hline $\begin{array}{l}\mathrm{CH}_{3} \\
\mathrm{CH}_{2} \mathrm{CH}_{3} \\
\mathrm{CH}_{2} \mathrm{OH}\end{array}$ & $\begin{array}{l}0.101 \pm 0.010 \\
0.072 \pm 0.011 \\
0.063 \pm 0.010\end{array}$ & $\begin{array}{l}0.058 \pm 0.002 \\
0.050 \pm 0.002 \\
0.066 \pm 0.005\end{array}$ & $\begin{array}{r}0.00 \\
0.28 \\
-0.82\end{array}$ & $\begin{array}{l}-0.035 \\
-0.020 \\
-0.015\end{array}$ \\
\hline $\begin{array}{l}\mathrm{CH}_{2} \mathrm{OCH}_{3} \\
\mathrm{CH}_{2} \mathrm{OC}_{6} \mathrm{H}_{5} \\
\mathrm{CH}_{2} \mathrm{~F}\end{array}$ & $\begin{array}{l}0.085 \pm 0.012 \\
0.214 \pm 0.030 \\
0.163 \pm 0.009\end{array}$ & $\begin{array}{l}0.076 \pm 0.001 \\
0.171 \pm 0.002 \\
0.119 \pm 0.002\end{array}$ & $\begin{array}{r}-0.27 \\
0.89 \\
-0.22\end{array}$ & $\begin{array}{l}-0.010 \\
-0.016 \\
-0.033\end{array}$ \\
\hline $\begin{array}{l}\mathrm{CH}_{2} \mathrm{Cl} \\
\mathrm{CHCl}_{2} \\
\mathrm{CCl}_{3}\end{array}$ & $\begin{array}{l}0.238 \pm 0.008 \\
0.393 \pm 0.031 \\
2.317 \pm 0.098\end{array}$ & $\begin{array}{l}0.182 \pm 0.003 \\
0.393 \pm 0.007 \\
1.507 \pm 0.009\end{array}$ & $\begin{array}{l}0.07 \\
0.44 \\
0.92\end{array}$ & $\begin{array}{l}-0.031 \\
-0.080 \\
-0.278\end{array}$ \\
\hline $\begin{array}{l}\mathrm{CH}_{2} \mathrm{Br} \\
\mathrm{CHBr}_{2} \\
\mathrm{CBr}_{3}\end{array}$ & $\begin{array}{l}0.184 \pm 0.014 \\
0.373 \pm 0.008 \\
1.769 \pm 0.075\end{array}$ & $\begin{array}{l}0.158 \pm 0.002 \\
0.312 \pm 0.003 \\
1.389 \pm 0.026\end{array}$ & $\begin{array}{l}0.20 \\
0.74 \\
1.18\end{array}$ & $\begin{array}{l}-0.033 \\
-0.068 \\
-0.180\end{array}$ \\
\hline $\begin{array}{l}\mathrm{CH}_{2} \mathrm{I} \\
\mathrm{CH}_{2} \mathrm{CN} \\
\mathrm{COCH}_{3}\end{array}$ & $\begin{array}{l}0.127 \pm 0.007 \\
0.411 \pm 0.032 \\
0.034 \pm 0.002\end{array}$ & $\begin{array}{l}0.181 \pm 0.012 \\
0.300 \pm 0.005 \\
0.019 \pm 0.004\end{array}$ & $\begin{array}{r}0.42 \\
-0.50 \\
-0.34\end{array}$ & $\begin{array}{l}-0.025 \\
-0.100 \\
-0.009\end{array}$ \\
\hline $\begin{array}{l}\mathrm{CO}_{2} \mathrm{CH}_{3} \\
\mathrm{CH}_{2} \mathrm{~N}\left(\mathrm{CH}_{3}\right)_{3}\end{array}$ & $\begin{array}{l}0.102 \pm 0.004 \\
0.030 \pm 0.003\end{array}$ & $\begin{array}{l}0.067 \pm 0.002 \\
0.031 \pm 0.002\end{array}$ & $\begin{array}{l}-0.37 \\
-1.23\end{array}$ & $\begin{array}{l}-0.052 \\
-0.031\end{array}$ \\
\hline
\end{tabular}

\footnotetext{
a Alkylating activities towards model nucleophiles NBP and nicotinamide; values are the means of six determinations.

b Partition coefficients determined by HPLC (Carlson et al., 1975).

c Rates of hydrolysis at $37^{\circ} \mathrm{C}$.
} 
of trichloropropylene oxide, epichlorohydrin and glycidol on chromosome aberrations and sisterchromatid exchange in cultured human lymphocytes. They found little differences in the epoxide order of potency, which is in great contrast to the relative alkylating ability and mutagenicity of the epoxides to Salmonella and E. coli, particularly for trichloropropylene oxide. They attributed the lack of activity by trichloropropylene oxide to its short half-life, reducing the amount of epoxide available for binding to DNA. Barber et al. (1983) examined time dependence of reversion in the standard PIA Ames test and found that the bacteria were most sensitive to mutagens $6-8 \mathrm{~h}$ after plating. If a chemical with a rapid decay rate was tested in the PIA, the initial dose of chemical would not be representative of the actual dose to the bacteria as reflected in the mutagenicity results. In LSA, exposure of the epoxide to bacteria occurs over a relatively short 2 -h incubation pe- riod. Exposure is halted by centrifugation of the bacteria and resuspension for plating in medium that no longer contains the test chemical. Thus, the effects of a short half-life would be less apparent in the LSA compared to the PIA. To test this hypothesis, epoxide decay rate, as measured by hydrolysis in an aqueous medium, was used as a parameter in comparing the two assays in the following equation: $\mathrm{TA}^{100_{\mathrm{LSA}}}=a$ $\left(\right.$ TA $\left.100_{\mathrm{PIA}}\right)+b$ (Decay) $+c$. The correlation coefficient for this equation increased to 0.98 , indicating that epoxide stability was a factor in explaining the differing results between the two methods.

The mutagenicity results for the propylene oxides also show differences between the two bacterial strains, TA100 and TA1535. The differences are illustrated in Fig. 2, which compares the results in the two strains using the LSA. It is apparent that there is general agreement be-

TABLE 3

MUTAGENICITY OF THE PROPYLENE OXIDES IN Salmonella typhimurium

\begin{tabular}{|c|c|c|c|c|}
\hline \multirow[t]{2}{*}{ Substituent } & \multicolumn{4}{|l|}{ Slope \pm S.E. ${ }^{\text {a }}$} \\
\hline & $\mathrm{TA} 100_{\text {LSA }}$ & TA100 ${ }_{\text {PIA }}$ & $\mathrm{TA}^{1535_{\mathrm{LSA}}}$ & $\mathrm{TA} 1535_{\mathrm{PIA}}$ \\
\hline $\begin{array}{l}\mathrm{CH}_{3} \\
\mathrm{CH}_{2} \mathrm{CH}_{3} \\
\mathrm{CH}_{2} \mathrm{OH}\end{array}$ & $\begin{array}{l}128 \pm 10 \\
188 \pm 12 \\
207 \pm 14\end{array}$ & $\begin{array}{r}18 \pm 4 \\
5 \pm \\
437 \pm 11\end{array}$ & $\begin{array}{r}43 \pm 2 \\
20 \pm 1 \\
113 \pm 3\end{array}$ & $\begin{array}{r}37 \pm 6 \\
4 \pm 1 \\
540 \pm 23\end{array}$ \\
\hline $\begin{array}{l}\mathrm{CH}_{2} \mathrm{OCH}_{3} \\
\mathrm{CH}_{2} \mathrm{OC}_{6} \mathrm{H}_{5} \\
\mathrm{CH}_{2} \mathrm{~F}\end{array}$ & $\begin{array}{l}253 \pm 10 \\
743 \pm 19 \\
229 \pm 16\end{array}$ & $\begin{array}{r}105 \pm 3 \\
1188 \pm 33 \\
157 \pm \quad 7\end{array}$ & $\begin{array}{r}25 \pm 1 \\
110 \pm 13 \\
49 \pm 2\end{array}$ & $\begin{array}{l}101 \pm 5 \\
759 \pm 26 \\
177 \pm 12\end{array}$ \\
\hline $\begin{array}{l}\mathrm{CH}_{2} \mathrm{Cl} \\
\mathrm{CHCl}_{2} \\
\mathrm{CCl}_{3}\end{array}$ & $\begin{array}{r}595 \pm 26 \\
5754 \pm 77 \\
14114 \pm 926\end{array}$ & $\begin{array}{l}182 \pm 5 \\
371 \pm 21 \\
294 \pm 21\end{array}$ & $\begin{array}{l}186 \pm 7 \\
199 \pm 12 \\
172 \pm 14\end{array}$ & $\begin{array}{r}273 \pm 11 \\
178 \pm 8 \\
23 \pm 2\end{array}$ \\
\hline $\begin{array}{l}\mathrm{CH}_{2} \mathrm{Br} \\
\mathrm{CHBr}_{2} \\
\mathrm{CBr}_{3}\end{array}$ & $\begin{array}{r}840 \pm 67 \\
4286 \pm 121 \\
21000 \pm 868\end{array}$ & $\begin{array}{r}432 \pm 32 \\
968 \pm 22 \\
6261 \pm 205\end{array}$ & $\begin{array}{l}290 \pm 29 \\
106 \pm 15 \\
243 \pm 25\end{array}$ & $\begin{array}{l}357 \pm 25 \\
217 \pm 10 \\
345 \pm 30\end{array}$ \\
\hline $\begin{array}{l}\mathrm{CH}_{2} \mathrm{I} \\
\mathrm{CH}_{2} \mathrm{CN} \\
\mathrm{COCH}_{3}\end{array}$ & $\begin{array}{r}741 \pm 78 \\
1898 \pm 61 \\
764 \pm 34\end{array}$ & $\begin{array}{l}585 \pm 41 \\
741 \pm 34 \\
245 \pm 5\end{array}$ & $\begin{array}{r}386 \pm 36 \\
278 \pm 9 \\
19 \pm 1\end{array}$ & $\begin{array}{r}358 \pm 38 \\
803 \pm 36 \\
79 \pm 6\end{array}$ \\
\hline $\begin{array}{l}\mathrm{CO}_{2} \mathrm{CH}_{3} \\
\mathrm{CH}_{2} \mathrm{~N}^{+}\left(\mathrm{CH}_{3}\right)_{3}\end{array}$ & $\begin{array}{r}138 \pm \\
41 \pm \quad 2\end{array}$ & $\begin{array}{ll}56 \pm & 1 \\
11 \pm & 2\end{array}$ & $\begin{array}{l}10 \pm 1 \\
23 \pm 1\end{array}$ & $\begin{array}{l}65 \pm 2 \\
13 \pm 1\end{array}$ \\
\hline
\end{tabular}

a Calculated slope (revertants $/ \mu$ mole) of the linear region on the dose-response curve \pm standard error. For each compound, the dose-response curve was determined from at least two independent experiments, with at least 5 doses tested (triplicate plating per dose) in each experiment. 
tween the two strains, excepting the di- and trihalogenated compounds, which show greater relative mutagenicity in TA100 than in TA1535. The two strains are genetically identical except that TA100 possesses a plasmid, pKM101, that codes for an error-prone DNA repair system. Errorprone repair systems are part of the SOS response in cells that undergo DNA damage. Since error-prone repair is an enzymatic system, bulkier DNA adducts might be better recognized by repair enzymes, leading to more error-prone repair from epoxides with larger substituent groups. A multiple regression model was tested as above, relating the mutagenicity in TA100 ${ }_{\mathrm{LSA}}$ to TA $1535_{\text {LSA }}$ but including the steric parameters: $\mathrm{TA}_{100} \mathrm{LSA}=a\left(\mathrm{TA} 1535_{\mathrm{LSA}}\right)+b($ Steric $)+c$. The correlation coefficient between the two strains alone was 0.33 for the LSA and 0.27 in the PIA, but when the STERIMOL $B_{1}$ value was included in the equation the correlation coefficient increased to 0.96 for LSA and 0.78 for PIA. While the results for the $B_{1}$ value, which is a measure of substituent group width (Verloop et al., 1976), may suggest that steric effects play a role in strain differences, such inferences should be made with caution since the range of values in the $B_{1}$ parameter is limited. Other possible causes of differences in mutagenic potency between the strains may relate to the alkylating strength of the epoxide or the type of adduct formed with DNA. The stronger alkylating epoxides, the di- and trihalogenated compounds, may cause greater levels of lethal damage to the bacterial DNA. This could result in greater induction of the SOS response, which allows the cells to repair lethal damage to DNA, but at the expense of accuracy in replication. Thus, a greater proportional increase in mutagenic activity is seen for those compounds with stronger alkylating ability. Furthermore, the reaction between epoxides and DNA can lead to imidazole ring-opening and depurination (Hemminki and Lax, 1986), where

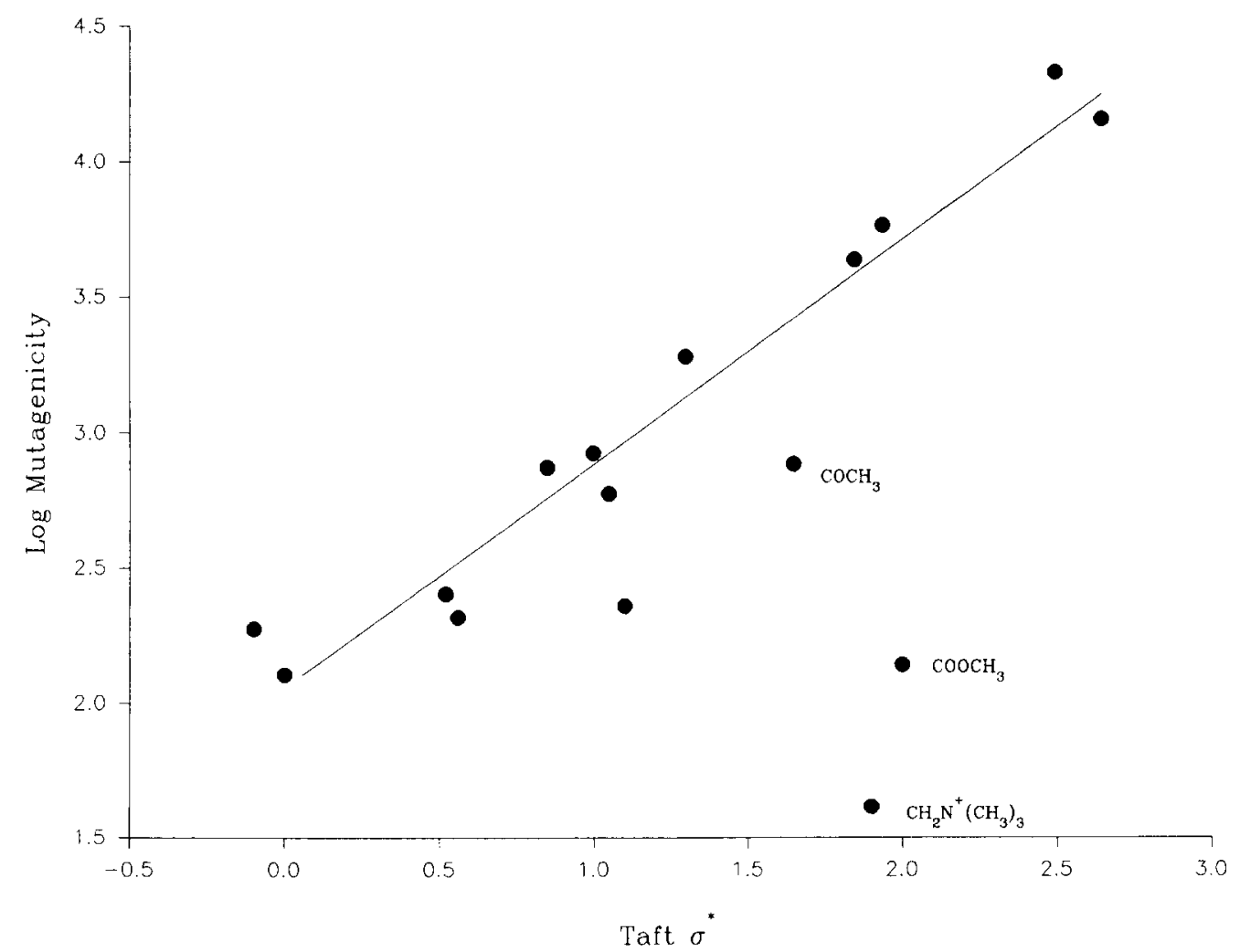

Fig. 1. The relationship between mutagenicity (revertants $/ \mu$ mole) in TA100, with the liquid suspension assay, and Taft $\sigma^{*}$ values. 


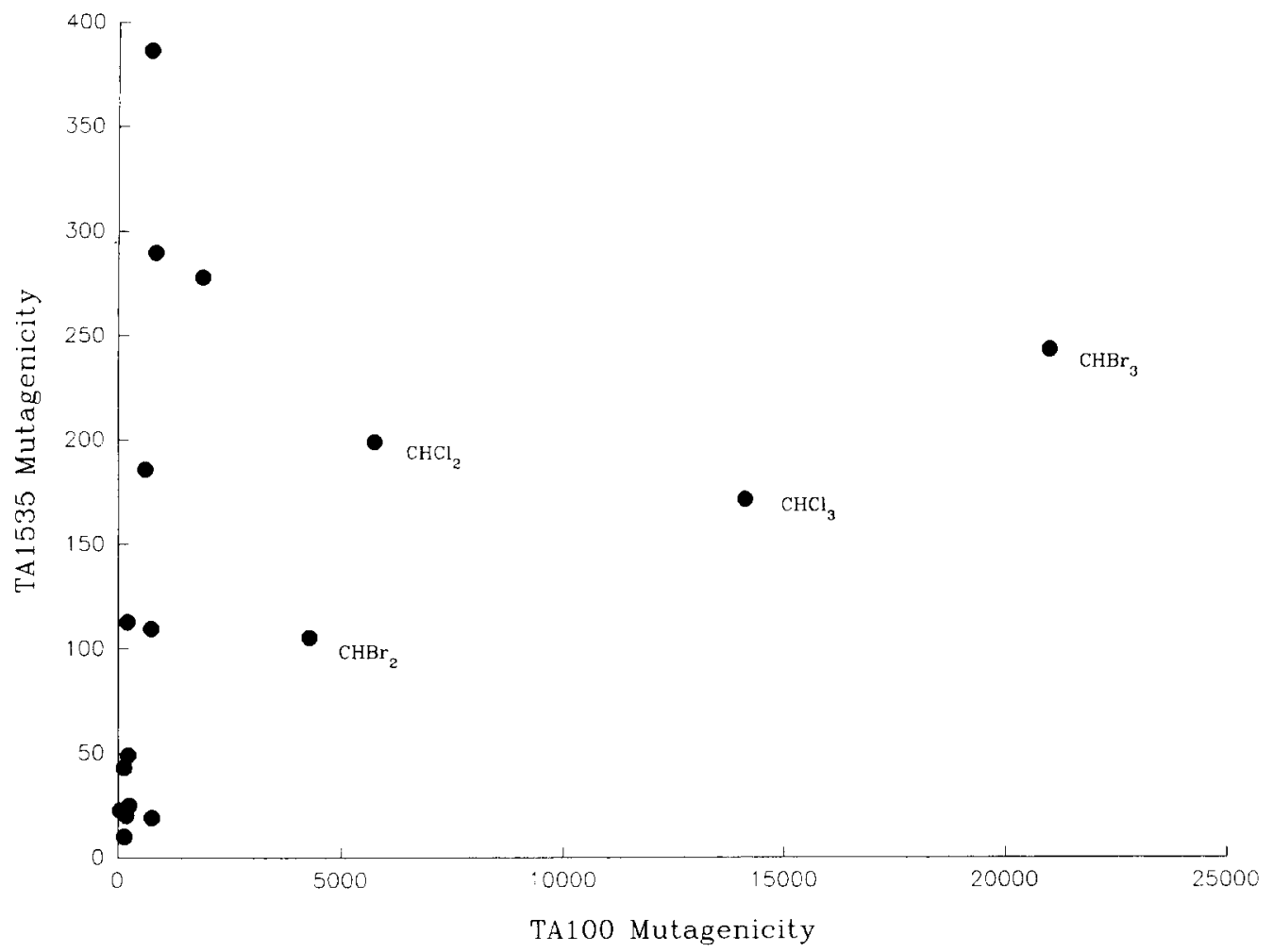

Fig. 2. Comparison of the mutagenicity results (revertants $/ \mu$ mole) in Salmonella typhimurium strain TA100 to those in strain TA1535, as determined using the liquid suspension assay.

the extent of ring-opening and depurination have been correlated to the electron-withdrawing strength of the epoxide substituent groups. These type of adducts may be more easily recognized by DNA repair systems, such as the error-prone repair system found in TA100. This could lead to increased mutagenicity in TA100 for those epoxides with high Taft $\sigma^{*}$ values, the di- and trihalogenated compounds.

Thus, the relative mutagenicity for our series of seventeen propylene oxides varies greatly among the four test systems studied. It is apparent that chemical reactivity is an important consideration in explaining these differences both as it may relate to the alkylation of DNA and to the half-life of the epoxides. Our previous in vivo results for trichloropropylene oxide and three other aliphatic epoxides (Giri et al., 1989, 1990) are analogous to the present in vitro Salmonella results in that compound stability, particularly that of the trichloro compound, is an important factor in explaining relative in vivo genotoxicity. It is interesting in this regard that while the present LSA results are highly correlated to epoxide reactivity, they may not be as predictive of epoxide genotoxicity in vivo as the PIA results since compound half-life is an important consideration both for in vivo and PIA studies.

\section{Acknowledgements}

This investigation was supported by grant R01 ES 03345 from the National Institute of Environmental Health Sciences, DHHS.

\section{References}

Barber, E.D., W.H. Donish and K.R. Mueller (1983) The relationship between growth and reversion in the Ames Salmonella plate incorporation assay, Mutation Res., 113, 89-101.

Bernstein, L., J. Kaldor, J. McCann and M.C. Pike (1982) An empirical approach to the statistical analysis of mutagene- 
sis data from the Salmonella test, Mutation Res., 97, 267-281.

Canter, D.A., E. Zeiger, S. Haworth, T. Lawlor, K. Mortelmans and W. Speck (1986) Comparative mutagenicity of aliphatic epoxides in Salmonella, Mutation Res., 172, 105138.

Carlson, R.M., R.E. Carlson and H.L. Kopperman (1975) Determination of partition coefficients by liquid chromatography, J. Chromatogr., 107, 219-223.

Djuric, Z., B.H. Hooberman, L. Rosman and J.E. Sinsheimer (1986) Reactivity of mutagenic propylene oxides with deoxynucleosides and DNA, Environ. Mutagen., 8, 369-383.

Ehrenberg, L., and S. Hussain (1981) Genetic toxicity of some important epoxides, Mutation Res., 86, 1-113.

Giri, A.K., E.A. Messerly and J.E. Sinsheimer (1989) Sisterchromatid exchange and chromosome aberrations for 4 aliphatic epoxides in mice, Mutation Res., 224, 253-261.

Giri, A.K., E.A. Messerly, P.K. Chakraborty, B.H. Hooberman and J.E. Sinsheimer (1990) DNA strand breaks in liver for four aliphatic epoxides in mice, Mutation Res., 242, 187-194.

Hammock, L.G., B.D. Hammock and J. Casida (1974) Detection and analysis of epoxides with 4-( $p$-nitrobenzyl)-pyridine, Bull. Environ. Contam. Toxicol., 12, 759-764.

Hansch, C., and A.J. Leo (1979) Substituent Constants for Correlation Analysis in Chemistry and Biology, Wiley, New York.

Hemminki, K., and K. Falck (1979) Correlation of mutagenicity and 4-( $p$-nitrobenzyl)pyridine alkylation by epoxides, Toxicol. Lett., 4, 103-106.

Hemminki, K., and M. Lax (1986) Stability of 7-alkyldeoxyguanosines of trichloropropylene oxide, epichlorohydrin and glycidol, Acta Pharmacol. Toxicol., 59, 80-85.

Karabatsos, G.J., D.J. Fenoglio and S.S. Lande (1969) Structural studies by nuclear magnetic resonance. XXI. Conformational analysis of dichloroacetaldehyde and dibromoacetaldehyde, J. Am. Chem. Soc., 91, 3572-3577.

Kolmark, G., and N.H. Giles (1955) Comparative studies of monoepoxides as inducers of reverse mutations in Neurospora, Genetics, 40, 890-902.

Manson, M.M. (1980) Epoxides-is there a human health problem?, Br. J. Ind. Med., 37, 317-336.

Maron, D.M., and B.N. Ames (1983) Revised methods for the Salmonella mutagenicity test, Mutation Res., 113, 173-215.

Moriguchi, I., Y. Kanada and K. Komatsu (1976) van der Waals volume and the related parameters for hydrophobicity in structure-activity studies, Chem. Pharm. Bull., 24, 1799-1806.

Neau, S.H., B.H. Hooberman, S.W. Frantz and J.E. Sinsheimer (1982) Substituent effects on the mutagenicity of phenylglycidyl ethers in Salmonella typhimurium, Mutation Res., 93, 297-304.

Nef, J.U. (1904) Dissociationsvorgange in der GlycolGlycerinreihe, Justus Liebigs Ann. Chem., 335, 181-333.

Nelis, H.J.C.F., and J.E. Sinsheimer (1981) A sensitive fluorometric procedure for the determination of aliphatic epoxides under physiological conditions, Anal. Biochem., 115, 151-157.

Nelis, H.J.C.F., S.C. Airy and J.E. Sinsheimer (1982) Comparison of the alkylation of nicotinamide and 4-( $p$-nitrobenzyl)pyridine for the determination of aliphatic epoxides, Anal. Chem., 54, 213-216.

Norppa, H., K. Hemminki, M. Sorsa and H. Vainio (1981) Effect of monosubstituted epoxides on chromosome aberrations and SCE in cultured human lymphocytes, Mutation Res., 91, 243-250.

Rosman, L.B., V.G. Beylin, V. Gaddamidi, B.H. Hooberman and J.E. Sinsheimer (1986) Mutagenicity of para-substituted $\alpha$-methylstyrene oxide derivatives with Salmonella, Mutation Res., 171, 63-70.

Rosman, L.B., V. Gaddamidi and J.E. Sinsheimer (1987) Mutagenicity of aryl propylene and butylene oxides, Mutation Res., 189, 189-204.

Rosman, L.B., P.K. Chakraborty, E.A. Messerly and J.E. Sinsheimer (1988) Mutagenicity of aromatic glycidyl ethers with Salmonella, Mutation Res., 206, 115-125.

Sinsheimer, J.E., E. van den Eeckhout, B.H. Hooberman and V.G. Beylin (1987) Detoxication of aliphatic epoxides by diol formation and glutathione conjugation, Chem.-Biol. Interact., 63, 75-90.

Van Duuren, B.L., S. Melchionne, R. Blair, B.M. Goldschmidt and C. Katz (1971) Carcinogenicity of isoesters of epoxides and lactones: aziridine ethanol, propane sulfone, and related compounds, J. Natl. Cancer Inst., 46, 143-149.

Verloop, A., W. Hoogenstraaten and J. Tipker (1976) Development and application of new steric substituent parameters in drug design, in: E.J. Ariens (Ed.), Drug Design, Vol. VII, Academic Press, New York, pp. 165-207.

von der Hude, W., S. Carstensen and G. Obe (1991) Structure-activity relationships of epoxides: induction of sisterchromatid exchanges in Chinese hamster V79 cells, Mutation Res., 249, 55-70.

Voogd, C.E., J.J. van der Stel and J.J.J.A.A. Jacobs (1981) The mutagenic action of aliphatic epoxides, Mutation Res., $89,269-282$.

Wade, D.R., S.C. Airy and J.E. Sinsheimer (1978) Mutagenicity of aliphatic epoxides, Mutation Res., 58, 217-223.

Wellman, G.R., B. Lam, E.L. Anderson and E. White (1976) A facile synthesis of 3,4-epoxybutanone, Synthesis, 8, 547548. 